\title{
A STUDY ON THE TRADE BALANCE BETWEEN CHINA AND U.S.: BASED ON
}

\section{COINTEGRATION ANALYSIS}

\section{YUGANG HE}

Research scholar, Department of International Trade, Graduate School, Chonbuk National University, South Korea

\begin{abstract}
There has been a long held belief that, the five variables (the export, the import, the nominal exchange rate, the disposable income in China, the disposable income in U.S.) are major factors that affect the trade balance between China and U.S. Therefore, this paper has empirically examined the impact of five variables on trade balance between China and U.S. for the period from 1990 to 2016. The trade balance between China and U.S. is regarded as the explained variable. The five variables are regarded as the explanatory variable. The cointegration test is employed, to estimate the impact of five variables on trade balance between china and U.S. The broad objective of this paper is, to analyze the impact of five variables on trade balance between China and U.S., based on time series data. The analysis is based on data extracted from the World Bank and the National Bureau of Statistics of the People's Republic of China. The results show that, the export, the nominal exchange rate and the U.S.'s disposable, income have a positive effect on trade balance between China and U.S. The China's disposable income and the import have a negative effect on trade balance, between China and U.S.
\end{abstract}

JEL Classifications: C02, F10, F31

KEYWORDS: Trade Balance, Five Variables \& Cointegration Test

Received: Sep 19, 2017; Accepted: Oct 08, 2017; Published: Nov 15, 2017; Paper Id.: IJECRDEC20173

\section{INTRODUCTION}

The trade balance (sometimes symbolized as NX) is the difference between the monetary value of a nation's exports and imports, over a certain period. Sometimes, a distinction is made between a balance of trade, for goods versus one for services. If a country's export value is greater than that of imports, it is called a trade surplus, positive balance or favorable balance and conversely, if a country's import value is greater than that of exports, it is called a trade deficit, negative balance or unfavorable balance.

The trade balance between China and U.S. has become an issue full of controversy, since China's GDP overtook that of Japan. A few months ago, the president of U.S., Donald John Trump, criticized that, China is a "currency manipulator", as soon as he took office shortly. He claimed that, he would sanction China in trade, by imposing higher taxation of the goods, importing from China. The reason is that, he thinks the source of high unemployment in U.S. is the great trade deficit, between China and U.S. Eventhough, his words are not supported by his partners, and he still gives pressure to China's government, through the name of currency manipulator. If so, he can curb the goods import from China, so as to increase the employment in U.S.

The statistics data from the United States, Department of Commerce, in 2016, the amount of export from U.S. to China is upto 115.78 billion dollars. However, the amount of import from China to U.S. is upto 462.81 
billion dollars. Obviously, the trade deficit between China and U.S. is greatly upto 347.03 billion dollars. This big trade gap between China and U.S., attracts quantities of scholars and experts to explore the reasons. Therefore, in this paper, a cointegration test is used and annual data-sets from 1990 to 2016 are applied to analyze the trade balance between China and U.S. More specific, this paper mainly focuses on the impact of the export, the import, the nominal exchange rate, the disposable income in China, the disposable income in U.S. on trade balance between China and U.S.

The rest of this paper is structured as follow: Section 2 will have reviewed on literature. Section 3 will provide the theoretical framework. Section 4 will present the result and interpretation. Section 5 will be the conclusion from this study.

\section{LITERATURE REVIEW}

The quest to keep a better trade balance has been the aim of every country especially developing countries including China. There have been numerous empirical studies in regards to the trade balance with different results and conclusions.

As for the shock to marginal efficiency of investment, Jacob and Peersman (2013) find that, it is more than half the forecast for cyclical fluctuations in U.S. trade. The shock of domestic and foreign marginal efficiency has a strong effect on imbalance variability via the transfer of international relative absorption.

Zhang and MacDonald (2014), have explored the equilibrium exchange rate, between 23 Organization for Economic Co-operation and Development countries and four immature economies. Their results show that, there is a significant relation between trade balance and net external assets. They also verify the relation between real exchange rate and trade balance. Due to these two relations, they find that the heterogeneity exists between emerging market economy and Organization, for Economic Co-operation and Development countries. In order to make the relation between trade balance and terms trade fully understood, Lopes and Sequeira (2014), try to find whether ten central and eastern Europe countries have an S-curve or not. Their empirical analysis results indicate that, the S-curve exists in Slovenia and Hungary. As for Bulgaria, Czech Republic and Slovakia, they have a weak S-curve. However, it prevails in these countries. In summary, ten central and eastern Europe countries have S-curve, strong or weak. The results support the S-curve, except for the technical shock, while domestic and imported goods are perfect substitutes. The technical shock is the decisive factor in explaining the S-curve pattern. And the transition countries seem to be experiencing some sort of technological shock. This model may disappear in the near future, so it is very important for these countries. Cruz, Diegues, Onofre and Andriotta (2014) find that, the trade between Brazil and China has become more intense in the most recent years mainly because the Brazilian exports have been more focused on commodities and natural resource-based products. Chinese exports to Brazil are more concentrated in products of high and medium-high-technology, based mainly on differentiated technology and scale, but with a wider range of products compared to the Brazilian exports. May be due to direct and indirect trade effects between two countries, Brazil's exports to China are going backwards. Schaling and Kabundi (2014) apply data from 1994 to 2011, to conduct an empirical analysis. The reliable statistical evidences show that, Net exports are driven by weaker real effective exchange rates, in the long run. However, this effect does not exist in the short run. Therefore, evidence to support the j-curve effect in South Africa can be found. Çebi and Çulha (2014), use vector auto regression model, to analyze the impact of shock of government expenditure on Turkey's real exchange rate and foreign trade balance, from the first quarter of 2004 to the fourth quarter of 2012. The results show that, the positive shock on government expenditure will result in real exchange rate appreciation and deterioration of trade balance. Still, they also find that, the structure of government expenditure is very important. The impact of the government on non-wage 
consumption has led to a rise in real exchange rates and deterioration in the trade balance. But, the impact of the government investment shock still remains paltry. Shah and Majeed (2014), find that, there is a long-run and short-run operating mechanism, among trade balance, income, money supply and real exchange rate in Pakistan from 1980 to 2011. The analysis is based on bounds testing approach, to co-integration and error correction models, developed within an autoregressive distributed lag framework. The result shows that, there is a steady and long-run relationship among trade balance, income, money supply and real exchange rate. More specifically, an increase in effective real exchange rate and real exchange rate appreciation has a negative effect on trade balance. Furthermore, the money supply is a determinant of trade balance in the long run, but not in the short. Via the analysis of variance decomposition and impulse response function, it can be found that, trade balance and effective real exchange rate have a long-run relationship with income. However, the long-run relationship between trade balance and money supply is not significant. In summary, the results suggest that, Marshal-Lerner Condition does not hold for trade balance. Wen (2014) figures out that, there is a long-run cointegration relationship between the RMB real effective exchange rate and ZhangzhouÂ's trade balance. However, these kinds of relationship are not so significant. Based on the Marshall-Lerner condition, Igue and Ogunleye (2014), try to find out whether real exchange rate depreciation has a positive effect on trade balance. Using Johansen test and vector error correction model, an empirical analysis is conducted to explore the long-run relationship, between trade balance and independent variables. The real exchange rate depreciation has a positive effect on trade balance in Nigeria, under the Marshall-Lerner condition. In other word, the depreciation of the exchange rate has had a positive effect on the long-term trade balance. The study also establishes that, a one percent depreciation in the exchange rate will improve trade balance, by 1.16 percent.

Tran, Nguyen, Nguyen and Huynh (2015), focus on identifying the relationship balance in Southeast Asia, from 2000 to 2014. It also compares the results, by dividing into each exchange rate regime ees group and analyzing the impact of exchange rate regime to trade balance. Chowdhury and Younus (2015), try to find out the impact of real exchange rate on export, import and trade balance in Bangladesh; the real exchange rate and the ratio of nominal exchange rate, to consumer price index, in terms of U.S. dollar. Of course, the trade-weighted real effective exchange rate is also used to analyze this topic. Mustafa, Rahman and Guru-Gharana (2015) find that the exchange rate depreciation between Brazil and U.S. can improve trade balance between them. However, it only works in the short run. Progressive improvement in trade balance in the long run would, in fact, depend on prudent monetary and fiscal actions to enhance Brazil's global competitiveness through improvement in labor productivity and modern technology adoption.

Bajo-Rubio, Berke and Esteve (2016), analyze the trade balance equation in Southern European countries. They use three different standards (consumer price index, export price and unit labor cost), to measure the real exchange rate. Their results provide a good explanation in evolution of trade balance and the demand seems to be more important, than relative prices. Onaran and Obst (2016), study the model of demand-led growth in the European Union's 15 countries. A decrease in wages, in national income will lead to a small increase in economic growth in Finland, France, Germany, Greece, Italy, Luxembourg, the Netherlands, Portugal, Spain, Sweden and the United Kingdom. However, this has a great positive effect on economic growth in Austria, Belgium, Denmark and Ireland. A decrease in the share of income also, can lead to a decrease in gross domestic products of European Union's, 15 countries. Therefore, the European Union's 15 countries are regarded as a whole, whose economy is wage-led. Moreover, the reason why there is a decrease in Austria and Ireland is that, the whole income level falls. The results indicate that, the decline in the wage share had significant negative effects on growth, in the EU15 and supports the case for wage coordination. They present different wage-led 
recovery scenarios and the effects on prices, investment and net exports.

Banerjee, Shi, Radovan, Sheng and Li (2017), examine in a multivariate context, the influence of both the exchange rate and structural factors on China's trade balance, vis-à-vis selected partner countries. Structural change is proxied by the evolution of the labour skill composition of trade. The empirical findings indicate that, China's large trade surplus cannot be attributed to exchange rate policy alone. The large persistent trade surplus also reflects improvement in non-price competitiveness, arising from the fact that, China's exports are rising up the skill ladder and imports are moving down the skill ladder. Njindan Iyke and Ho (2017), study the effects of real exchange rate changes on the trade balance of Ghana, during the period 1986Q1 to 2016Q3. They find no evidence in support of the short- and long-run impact of exchange rate changes on the trade balance, in the linear specification. The J-curve is refuted in this case. In contrast, exchange rate changes affected the trade balance, in the nonlinear specification. Depreciation improves the trade balance in the long run, but appreciations have no impact. Hence, exchange rate changes have nonlinear effects, on the trade balance. This is consistent with the J-curve phenomenon. Bahmani-Oskooee, Ghodsi and Halicioglu (2017), use monthly data over the period 2000M1-2016M11, to assess response of U.K. trade balances with each of its 19 trading partners. When a linear ARDL model was estimated, they find short-run symmetric effects in the U.K. trade balance with 11 partners, that lasted into the long-run symmetric effects in only five cases. However, when they shift to a nonlinear ARDL model, they find short-run asymmetric effects with 14 partners, which lasted into the long-run asymmetric effects in eight cases. The longrun effects are adverse in most cases, which could be due to inelastic import demands. Arize (2017) suggests another effective method is, to obtain long-term parameters and their test statistics. He offers a simple way, to implement a user friendly and portable approach that allows us not only to study long-term relationships, but also to study short-term dynamics. Furthermore, this approach can be used, without buying new software, and it may be indispensable in the face of tighter spending budgets and improved student education costs. Finally, he verifies the approach, by using U.S.'s trade balance to prove his approach. Ousseini and Aboubacar (2017) figure out that, the money supply and household consumption expenditure have a negative effect on trade balance. Meanwhile, they also find that, the real exchange rate, income and inflation have a positive effect on input of trade balance. The real exchange rate, income and household consumption expenditure also have a positive effect on current account. The importance of exchange rate effect on trade balance shows that, the Marshall-Lerner condition holds for WAEMU. Arize, Malindretos and Igwe (2017) estimate the effective exchange rate, can impact the trade balance of the eight countries, under nonlinear auto-regressive distributed lag model. The advantage of it is that, it presents more effective short-term and long-term estimated coefficients. And, it allows for a single common cross product vector by distribution delay and long term dynamics, both of which are asymmetrical. Previous studies have relied on models that ignore the time series properties of variables, while some models use linear enthusiasm and get mixed results. The current papers use a nonlinear self-regression distribution lag model, which indicates that this is due to the assumption that the relationship is symmetric. Evidence is provided from the analysis of short-term analysis. It is shown that when depreciation and appreciation are separated, it has obvious influence on trade balance, but in asymmetric model.

\section{THEORETICAL FRAMEWORK}

In economic theory, the trade balance of a country is mainly affected by the export and import. In order to address the impact of export and import on trade balance more clearly, the disposable income and the nominal exchange rate are introduced. Then, the analysis will be performed via two aspects (terms of import trade and terms export trade). 


\subsection{In Terms of Import Trade}

There are two major determiners for a country's import: One is the disposable income of a country. Specifically, if the disposable income of a country reaches a high level, the demand of foreign goods will be enlarged. Conversely, if the disposable income of a country locates in a low level, the demand of foreign goods will be reduced. The other is the nominal exchange rate. Concretely speaking, the nominal exchange rate will be reflected to the relative price of foreign goods in domestic market. If the price of foreign goods is lower than that of domestic goods, the demand of foreign goods will be increased. In the contrast, if the price of foreign goods is higher than that of domestic goods, the demand of foreign goods will be decreased.

In statistics, the demand of import function for domestic country gives:

$$
I M=\alpha_{0}+\alpha_{1} D I^{d}+\alpha_{2} N E R+\varepsilon_{\alpha}
$$

Where $I M$ is the import; $D I^{d}$ is the domestic disposable income; $N E R$ is the nominal exchange rate; $\varepsilon_{\alpha}$ is the while noise; $\alpha_{0}$ is a constant; $\alpha_{1}$ and $\alpha_{2}$ are estimated coefficients.

\subsection{In terms of Export Trade}

There are also two major determiners for a country's import: One is the foreign disposable income of a country. Specifically, if the foreign disposable income reaches a high level, the demand of domestic goods will be enlarged. Therefore, the foreign country will import goods from the domestic country. The domestic country's export will be increased. Conversely, if the foreign disposable income locates in a low level, the demand of domestic goods will be reduced. So, the export of domestic country will be decreased. The other is the nominal exchange rate. More concretely, the nominal exchange rate will be reflected to the relative price of domestic goods in foreign market. If the price of domestic goods is lower than that of foreign goods, the demand of domestic goods will be increased. So the domestic country will export more than before. In contrast, if the price of domestic goods is higher than that of foreign goods, the demand of domestic goods will be decreased. So, the domestic country's export will be decreased.

In statistics, the demand of export function for domestic country gives:

$$
E X=\beta_{0}+\beta_{1} D I^{f}+\beta_{2} N E R+\varepsilon_{\beta}
$$

Where $E X$ is the export; $D I^{f}$ is the foreign disposable income; $N E R$ is the nominal exchange rate; $\varepsilon_{\beta}$ is the while noise; $\beta_{0}$ is a constant; $\beta_{1}$ and $\beta_{2}$ are estimated coefficients.

Subtracting (2) by (1) gives:

$$
B T=E X-I M=\left(\beta_{0}-\alpha_{0}\right)+\beta_{1} D I^{f}-\alpha_{1} D I^{d}+\left(\beta_{2}-\alpha_{2}\right) N E R+\varepsilon_{\beta}-\varepsilon_{\alpha}
$$

Rewriting equation (3) gives:

$$
B T=\gamma_{0}+\gamma_{1} D I^{f}+\gamma_{2} D I^{d}+\gamma_{3} N E R+\varepsilon_{\gamma}
$$

Where $B T$ is the trade balance; $D I^{f}$ is the foreign disposable income; NER is the nominal exchange rate; 
$\varepsilon_{\gamma}=\varepsilon_{\beta}-\varepsilon_{\alpha}$ is the while noise; $\gamma_{0}=\beta_{0}-\alpha_{0}$ is a constant; $\gamma_{1}=\beta_{1}$ and $\gamma_{2}=-\beta_{2}$ are estimated coefficients.

\section{EMPIRICAL ANALYSIS}

\subsection{Data Description}

A sample period of 27 years has been selected for this paper for the period from 1990 to 2016 with annual time series. Different sources are used to collect the data. The amount of export and import, trade balance, and nominal exchange rate are obtained from the National Bureau of Statistics of the People's Republic of China. The China's GDP and U.S.' GDP are collected from the World Bank. It is hard to seek the disposable income of China and U.S, so the disposable in this paper is replaced by the real GDP of the two countries. Due to the heteroscedasticity, all variables are taken the logarithm. All variables are shown in table 1.

Table 1: Variables

\begin{tabular}{|l|c|l|}
\hline \multicolumn{1}{|c|}{ Variable } & Logarithmic Form & \multicolumn{1}{c|}{ Source } \\
\hline Amount of export & $\log E X$ & $\begin{array}{l}\text { National Bureau of Statistics of the People's } \\
\text { Republic of China }\end{array}$ \\
\hline Amount of import & $\log B T$ & $\begin{array}{l}\text { National Bureau of Statistics of the People's } \\
\text { Republic of China }\end{array}$ \\
\hline Trade balance & $\begin{array}{l}\text { National Bureau of Statistics of the People's } \\
\text { Republic of China }\end{array}$ \\
\hline Nominal exchange rate & $\log N E R$ & $\begin{array}{l}\text { National Bureau of Statistics of the People's } \\
\text { Republic of China }\end{array}$ \\
\hline China's GDP & $\log C g d p$ & World bank \\
\hline U. S.'s GDP & $\log U g d p$ & World bank \\
\hline
\end{tabular}

\subsection{Unit Root Test}

The Augmented Dicky-Fuller test is performed to test whether a variable has the unit root or not. The testing models give:

$$
\begin{aligned}
& \text { Model 1: } \Delta X_{t}=\delta X_{t-1}+\sum_{i=1}^{m} \beta_{i} \Delta X_{t-1}+\varepsilon_{t} \\
& \text { Model 2: } \Delta X_{t}=\alpha+\delta X_{t-1}+\sum_{i=1}^{m} \beta_{i} \Delta X_{t-1}+\varepsilon_{t} \\
& \text { Model 3: } \Delta X_{t}=\alpha+\beta \mathrm{t}+\delta X_{t-1}+\sum_{i=1}^{m} \beta_{i} \Delta X_{t-1}+\varepsilon_{t}
\end{aligned}
$$

The null hypothesis, $H_{0}: \delta=0$, one unit root exists; An alternative hypothesis, $H_{1}: \delta \neq 0$, a unit root does not exist.

The difference between model 1 and the other two models is that the other two models have a constant and trend term or only have a constant. Actually, the proper order to test the sequence is from the model 3 , then the model 2 , to the model 1. Any test that rejects the null hypothesis means that its original sequence does not have a unit root. As long as one of the results from any of the models rejects the null hypothesis, the original hypothesis can be considered to be stationary. When all of the testing results of the three models do not reject the null hypothesis, the original sequence can be considered to be non-stationary. And then, the first order difference sequence should be tested, and the procedures above should be 
repeated.

Table 2: Unit Root Test

\begin{tabular}{|c|c|c|c|}
\hline Variable & T-Statistic & $\begin{array}{c}\text { 5\% Test } \\
\text { Critical Value }\end{array}$ & Prob.* \\
\hline $\log E X$ & -1.928 & -3.040 & 0.313 \\
\hline $\log I M$ & -2.095 & -3.040 & 0.249 \\
\hline $\log B T$ & -1.389 & -3.040 & 0.564 \\
\hline $\log N E R$ & -1.620 & -3.052 & 0.452 \\
\hline $\log C g d p$ & -3.007 & -3.081 & 0.057 \\
\hline $\log U g d p$ & -1.070 & -3.052 & 0.702 \\
\hline$D \log E X$ & -6.468 & -3.066 & 0.000 \\
\hline$D \log I M$ & -5.656 & -3.066 & 0.000 \\
\hline$D \log B T$ & -3.368 & -3.052 & 0.028 \\
\hline$D \log N E R$ & -3.740 & -3.066 & 0.014 \\
\hline$D \log C g d p$ & -3.992 & -3.081 & 0.009 \\
\hline$D \log U g d p$ & -4.114 & -3.066 & 0.007 \\
\hline
\end{tabular}

$D$ Represents the first difference of all variables

Table 2 shows all variables are non-stationary under the 5\% significance level. However, after the first difference, all of them become stationary under the 5\% significance level. According to the Granger representation theorem (it states that a cointegrated vector autoregressive process can be decomposed into four components: a random walk, a stationary process, a deterministic part, and a term that depends on the initial values), the cointegration can be conducted further.

\subsection{Cointegration Test}

To the cointegration analysis of the non stationary time series, there are two methods: on the E-G two stage method which can only recognize one cointegration among many variables (more than one). The other is the Johansen cointegration test, which can recognize more than cointegrations. Therefore, the Johansen cointegration test will be used to verify, whether there is the conintegrated relationship, among all variables. The cointegration test results are shown in table 3 and table 4 .

Table 3: Unrestricted Cointegration Rank Test (Trace)

\begin{tabular}{|l|c|c|c|c|}
\hline $\begin{array}{c}\text { Hypothesized no. of } \\
\text { CE(S) }\end{array}$ & Eigen value & Trace Statistic & $\begin{array}{c}\text { 0.05 Critical } \\
\text { Value }\end{array}$ & Prob.** \\
\hline None $*$ & 0.980 & 186.192 & 95.754 & 0.000 \\
\hline At most 1* & 0.940 & 108.123 & 69.819 & 0.000 \\
\hline At most 2 $*$ & 0.772 & 51.922 & 47.856 & 0.020 \\
\hline At most 3 & 0.462 & 22.314 & 29.797 & 0.281 \\
\hline At most 4 & 0.369 & 9.899 & 15.495 & 0.289 \\
\hline At most 5 & 0.034 & 0.696 & 3.841 & 0.404 \\
\hline
\end{tabular}

Trace test indicates 3 cointegrating eqn(s) at the 0.05 level. * denotes rejection of the hypothesis at the 0.05 level. **MacKinnon-Haug-Michelis (1999) p-values

Table 3 indicates the results of trace test. From the p-value, it can be known that there at most 2 cointegrations under $5 \%$ significant level. 
Table 4: Unrestricted Cointegration Rank Test (Maximum Eigen value)

\begin{tabular}{|l|c|c|c|c|}
\hline $\begin{array}{c}\text { Hypothesized no. of } \\
\text { CE(S) }\end{array}$ & Eigen value & $\begin{array}{c}\text { Max-Eigen } \\
\text { Statistic }\end{array}$ & $\begin{array}{c}\text { 0.05 Critical } \\
\text { Value }\end{array}$ & Prob.** \\
\hline None $*$ & 0.980 & 78.069 & 40.078 & 0.000 \\
\hline At most 1 $*$ & 0.940 & 56.201 & 33.879 & 0.000 \\
\hline At most 2 & 0.772 & 29.608 & 27.584 & 0.027 \\
\hline At most 3 & 0.462 & 12.416 & 21.132 & 0.507 \\
\hline At most 4 & 0.369 & 9.202 & 14.265 & 0.270 \\
\hline At most 5 & 0.034 & 0.696 & 3.841 & 0.404 \\
\hline
\end{tabular}

Max-eigen value test indicates 3 cointegrating eqn(s) at the 0.05 level. * denotes rejection of the hypothesis, at the 0.05 level. **MacKinnon-Haug-Michelis (1999) p-values.

Table 4, indicates the results of max- Eigen value test. It also shows that, there are at most 2 cointegrations, under 5\% significant level. Combined with table 3 and table 4, it suggests that, there is a long-run relationship among all variables. Table 5, shows estimated coefficients of the long-run relationship among them.

Table 5: Cointegrating Equation

\begin{tabular}{|c|c|c|c|c|c|}
\hline $\log B T$ & $\log U g d p$ & $\log C g d p$ & $\log E X$ & $\log I M$ & $\log N E R$ \\
\hline \multirow{2}{*}{1.000} & 0.541 & -0.197 & 1.928 & -0.942 & 0.547 \\
& $(0.122)$ & $(0.050)$ & $(0.021)$ & $(0.044)$ & $(0.173)$ \\
\hline
\end{tabular}

Note: Normalized cointegrating coefficients (standard error in parentheses)

The specific estimated equation gives:

$\log B T=0.541 \log U g d p-0.197 \log C g d p+1.928 \log E X-0.942 \log I M+\log N E R$

Equation (8) demonstrates that, the specific effect of each variable on trade balance between China and U. S. $1 \%$ increase in the U.S.'s disposable income can result in $0.541 \%$ in the trade balance. $1 \%$ increase in the China's disposable income can lead to $0.197 \%$ decrease in the trade balance. $1 \%$ increase in the export can bring about $1.928 \%$ increases in the trade balance. $1 \%$ increase in the import can generate $0.942 \%$ decrease in the trade balance. $1 \%$ in the nominal exchange rate can give rise to $0.547 \%$ increase in the trade balance. The results of this estimation accord with theory in economics and practical situation between China and U.S. More importantly, the estimated results also show that the export plays a significant role in the trade balance between China and U.S. at present. Of course, the appreciation of exchange rate also can promote the favorable balance between China and U.S. Therefore, China's government should spare no effect to encourage to the export as keeping the trade balance between China and U.S., favourable.

\section{CONCLUSIONS}

The aim of this paper is to study the trade balance between China and U.S. The annual data-sets from 1990 to 2016 are applied, to conduct a cointegration analysis. The results show that, the export, the nominal exchange rate and the U.S.'s disposable income, have a positive effect on the trade balance between China and U.S. The China's disposable income and the import have a negative effect, on the trade balance between China and U.S. This provides some ways for China, to keep the favorable balance between China and U.S. For example, China's government can lower the goods's price (increase the nominal exchange rate) and collect more tax (decrease China's disposable income). In summary, China's government should open the domestic market more to the world, as to maintain a better trade balance. In the aspect of U.S., the U.S.' government, should try its best to make its product more competitive in the foreign market, so as to improve its trade deficit. 


\section{REFERENCES}

1. Arize, A. C. (2017). A convenient method for the estimation of ARDL parameters and test statistics: USA trade balance and real effective exchange rate relation. International Review of Economics \& Finance, 50, 75-84.

2. Arize, A. C., Malindretos, J., \& Igwe, E. U. (2017). Do exchange rate changes improve the trade balance: An asymmetric nonlinear cointegration approach? International Review of Economics \& Finance, 49, 313-326.

3. Bahmani-Oskooee, M., Ghodsi, S. H., \& Halicioglu, F. (2017). UK trade balance with its trading partners: An asymmetry analysis. Economic Analysis and Policy.

4. Bajo-Rubio, O., Berke, B., \& Esteve, V. (2016). The effects of competitiveness on trade balance: The case of Southern Europe. Economics: The Open-Access, Open-Assessment E-Journal, 10(2016-30), 1-27.

5. Banerjee, B., Shi, H., Radovan, J., Sheng, Y., \& Li, X. (2017). The Impact of the Exchange Rate and Trade Composition on China's Trade Balance Vis-à-Vis Selected Partner Countries. Comparative Economic Studies, 59(3), 311-344.

6. Çebi, C., \& Çulha, A. A. (2014). The effects of government spending shocks on the real exchange rate and trade balance in Turkey. Applied Economics, 46(26), 3151-3162.

7. Chowdhury, M., \& Younus, S. (2015). Real Exchange Rate and its Impact on Export, Import and Trade Balance: Is There any J Curve Effect in Bangladesh? (No. id: 7985).

8. Cruz Jr, J. C., Diegues Jr, A. C., Onofre, V. S., \& Andriotta, A. B. (2014, November). The Effect Of The Chinese International Trade On The Brazilian Trade Balance. In ERSA conference papers (No. ersal4p1590). European Regional Science Association.

9. Ferreira Lopes, A., \& Neves Sequeira, T. (2014). The dynamics of the trade balance and the terms of trade in Central and Eastern European countries. Acta Oeconomica, 64(1), 51-71.

10. Igue, N. N., \& Ogunleye, T. S. (2014). Impact of real exchange rate on trade balance in Nigeria. African Development Review, 26(2), 347-358.

11. Jacob, P., \& Peersman, G. (2013). Dissecting the dynamics of the US trade balance in an estimated equilibrium model. Journal of International Economics, 90(2), 302-315.

12. Mustafa, M., Rahman, M., \& Guru-Gharana, K. K. (2015). Brazil-US trade balance and exchange rate: Dynamic empirics. The Journal of Developing Areas, 49(3), 151-164.

13. Njindan Iyke, B., \& Ho, S. Y. (2017). The Real Exchange Rate, the Ghanaian Trade Balance, and the J-curve.

14. Onaran, O., \& Obst, T. (2016). Wage-led growth in the EU15 member-states: the effects of income distribution on growth, investment, trade balance and inflation. Cambridge Journal of Economics, 40(6), 1517-1551.

15. Ousseini, A. M., Hu, X., \& Aboubacar, B. (2017). WAEMU Trade and Current Account Balance Deficit Analysis: A Panel VAR Approach. Theoretical Economics Letters, 7(04), 834.

16. Schaling, E., \& Kabundi, A. (2014). The exchange rate, the trade balance and the J-curve effect in South Africa. South African Journal of Economic and Management Sciences, 17(5), 601-608.

17. Shah, A., \& Majeed, M. T. (2014). Real exchange rate and trade balance in Pakistan: An ARDL co-integration approach.

18. Tran, L. D., Nguyen, Q. A., Le, M. H., Nguyen, C. T., \& Huynh, M. T. (2015). The effect of changes in foreign exchange rate to trade balance of ASEAN's countries (Doctoral dissertation, FUG HCM). 
19. Wen, L. (2014). Study of the impact of RMB real exchange rate on zhangzhoũ̃ Âs trade balance. BioTechnology: An Indian Journal, 10(20).

20. Zhang, G., \& MacDonald, R. (2014). Real exchange rates, the trade balance and net foreign assets: long-run relationships and measures of misalignment. Open Economies Review, 25(4), 635-653. 